ANETTA BARSKA

\title{
Attitudes of young consumers towards innovations on the food market
}

Ph.D. Anetta Barska University of Zielona Góra

Faculty of Economics and Management

\section{Introduction}

Development of European food market is significantly determined by new economic and social conditions, being result among others of extending the number of European Union members. Among new phenomena in consumption should be listed: taking care of health, good condition, comfort accompanied with servicization ${ }^{1}$ and dematerialization ${ }^{2}$ of consumption, homocentrism ${ }^{3}$ and privatization $^{4}$ of consumption ecoconsumption, prosumption ${ }^{5}$, mediatisation and virtualization as well as heterogenisation and glocalization ${ }^{6}$ (Bywalec 2010, pp. 194-

1 Servicization of consumption -growth of consumption of services greater presence of modern and new services, related to, for example, free time

2 Dematerialization of consumption means a growth of consumption of non-materialistic values (information, knowledge, aesthetic experiences, improvement of health and mood)

3 Homocentrism - moving of activity and all types of consumption into homes, equipping home with equipment for transmission of information and culture (Słaby 2010, p.16).

4 Privatization of consumption is interpreted in two ways. In the first case, it can be understood as a process of commercialization that is, turning public consumption into private consumption. In the second case, it is the so-called process of individualization of consumption.

5 Prosumption means using of consumers in order to work out innovative solutions. Primarily, according to the conception of Alvin Toffler, prosumption was understood, above all, as shifting some tasks to consumers - according to the conception of "do it yourself” (Toffler 1997).

6 Glocalization is understood as a growing importance of local communities and economies functioning in conditions created by integrative processes. It is a preservation of cultural regionalisms and local identity (Bywalec 2010, p. 210). 
239). New trends favours the change of the consumers behaviours that manifest in the searching of ecological products, paying attention to safety of the products, simplification of meals preparation or in fast purchasing (Zalewski 2004, p. 353). On the other hand, there are many individual conditions determining purchase behaviours: personal (age, cycle of family life, gender, income situation), psychological (motivations, perceptions, experiences from the past), social and cultural (social roles, reference groups). Consumer is an invaluable source of information, indispensable for the producers during preparation of marketing strategies connected with designing and introduction of new products to the market. Knowledge of attitudes and behaviours of the consumers towards innovations can significantly contribute to the growth of subject innovativeness. The goal of this article is identification attitudes of young consumers towards innovations on the food market. The author used an analysis of the subject literature and results of her own surveys conducted among 791 respondents, who were chosen from the age group of 18-29 years, from the border areas of Poland, Czech Republic, Slovakia and Germany. Research were conducted in 2013.

\section{Innovation of food products, and behavior of consumers}

The topical literature seeks to define the essence of innovation in various ways. As observed by K. Karcz, the semantics of the term innovation results from the scope of conducted analyses, the selection of the approach as well as the very interpretation of the idea of novelty (Karcz 2004, p. 15). The term, as opined by $\mathrm{Ph}$. Kotler, signifies "any product, service or idea, which is perceived by somebody as new. This idea can exist for a very long time, but constitutes an innovation for the person who perceives it as new" (Kotler 2004, p.222). It is worth noting, however, that from a marketing point of view all actions related both to innovativeness and imitation should take into consideration the value for the client, and not only effectiveness of competing with other entities. Main motive for creation of marketing innovations by companies is a need to gain financial means and interest of purchasers (Pilarczyk 2011, p. 271). Whereas globalization and technological progress are conditionings for taking actions (Frąckiewicz 2004, p. 314). It is also worth to observe at this juncture that the new political-economic conditions, being the result of political-economic transformation, strengthened by the bigger number of EU members, influenced markedly the transformation of consumer behavior. Market behavior of consumers determines the actions related to searching, purchasing, using and 
evaluating of both goods and services that fulfill needs. Under the influence of the changing surroundings numerous changes occur such as the evolution of needs and expectations of individual consumers (Makarski 2013, p.214). Market behavior of consumers determines the actions related to searching, purchasing, using and evaluating of both goods and services that fulfill needs.

Analysis of consumer behaviours on the food market shows that they are implicated, on the one side by the feeling of hunger and internalized norms of consumption and on the other side by the impact of particular elements of food marketing, as well as conditions of social and cultural and economic environment. Consumers expect from food within this scope: vitality, health, beauty, growth of consuming pleasure. Modern consumer of food products is characterized by:

- choice of producers using different technologies,

- different level of education and experiences with other cultures, including national and regional cuisines,

- progressive diversification within the scope of expectations towards food,

- growing interest in food favouring health, beauty, physical condition,

- growing interest in rules of rational nutrition and meaning of sources of information about food,

- progressive diversity of particular segments of consumers that separate themselves on the basis of new criteria of typology,

- varied income that contribute to change of expectations and much higher acceptability of innovative solutions,

- awareness of consumers within legal protection of their interests (Gutkowska, Ozimek 2005, pp. 11-21).

Modern food market is a market with a high level of innovativeness, what is a consequence of more and more differentiated expectations of consumers, not only about the hunger, but also various hedonistic desires, keeping slender figure, increasing vital forces, saving time, or protection of environment (Gutkowska 2011, p. 109). New macro trends in consumption, which source are changes in the level and distribution of income (Mruk 2007, p. 10), as well as internal conditionings of purchasers have significant impact on their purchasing behaviours. Consumer behaviour that manifests with a search for ecological products, paying attention to the safety of products or fast shopping. Functional food is becoming more and more popular, also eating habits are changing (e.g. development of "light" products). On the other side, there are many individual conditionings that determine purchasing behaviours: personal (age, cycle of family life, gender, financial situation), psychological (motivations, perceptions, 
experiences from the past), social and cultural(social roles, reference groups. It concerns especially young consumers and they enable extension of enterprise offer.

Because behaviours of consumers and other participants of the market are significantly changing (Wziątek-Kubiak, Balcerowicz 2009) companies compete to satisfy their preferences through innovations. In conditions of the necessity of fast reaction for requirements of dynamic market, knowledge of attitudes and behaviours of the consumers towards innovations can significantly contribute to the growth of innovativeness of subjects. In this place, it is worth mentioning the position of K. Mazurek-Łopcińska: „behaviours of purchasers should be a source of inspiration for entrepreneurs and the basis of modelling and verification of market decisions" (Mazurek-Łopacińska 2003, p. 11).

.According to the Arthur D's report: Littre The Future of Innovation Management: The Next 10 Years the strongest (Taranko 2013, p. 2) trend changing the attitude to creating products will be the changes of behavior of consumers and the necessity to include those changes in the innovation processes

Studies in the area of innovation on the food market shows that modern market is "flooded" with a large number of different groceries and that is why a consumer starts to "lose" itself in determination of which product is new one and which one is not. It should also be noted that studies on consumer behaviour towards innovations of marketing food products are difficult due to complexity of attitudes and reactions of consumers to innovation, and also their subjectivism in defining innovations. We can find two areas of research on innovativeness in literature - general connected with $\mathrm{z}$ examination of intellectual and perceptive tendencies to innovative behaviours and specialised oriented to behaviours towards innovations within certain groups of products (Citrin, Sprott, Silverman, Stem 2000) because there is no basis to generalize innovativeness of consumers in different categories of products (Goldsmith, Flynna 1992, pp. 42-55). We should also mention a concept of E. Rogers (1983, p. 16), who made a segmentation of clients according to the rate of acceptance of new products and has distinguished: innovators (about $2,5 \%$ of population), early followers ( $13,5 \%$ of population), early majority ( $34 \%$ of population), late majority ( $34 \%$ of population) and dawdlers ( $16 \%$ of population). Research about attitudes towards new products in relation to food are undertaken relatively seldomthere have been many studies of McCarthy, Y. O'Sullivan, Z. O'Reilly (in 1999 r), S.S. Ling, D. T. Pysarchik, F.J. Choo (in 2004 ) and H. J. Choo, J-E. Chung, D. T. Pysarchik (in 2004) (Kowalczuk 2011, p. 47). Results concerning innovativeness of Polish consumers are presented in Polish literature (Mazurek-Łopacińska 
2003; Gutkowska, Ozimek 2005; Jeżewska-Zychowicz 2008; Kowalczuk 2011) however they do not concern precisely defined age group and their territorial scope mainly concern Poland.

\section{Researching method}

In research proceedings was useful both secondary and primary sources of information. Research proceedings were commenced from analyses of literature within the scope of researched areas. Field researchcommenced from conceptualization and operationalization of terms. Auditorium and internet survey was applied. A questionnaire survey was conducted on the sample of young consumers in the 18-29 age group, living in border regions of Czech Republic, Germany, Poland and Slovakia. Research were of comparative character, they were done at the same time in researched markets with the application of the same methods and measuring tools. Taking into account the problem of equivalence in international research in elaboration of measuring tool applied was return translation 7 , what will enable to discover most of the differences connected with translation. Questionnaire was prepared in Polish, German, Slovakian and Czech language. Before commencement of proper research, were carried out pilot research, which enabled verification of measuring tool and elimination of potential irregularities. Alph-Cronbach test was used for the assesment of scale reliability of measures. In research, value of 0,776 was assumed, what means appropriate scale reliability. Hampered access to sampling frame, as well as international character of research caused that the Author applied sampling with the technique of snowball. Survey were carried out in 2013 among 811 consumers in 18-29 age group coming from Czech Republic, Gremany, Poland and Slovakia.In research proceedings were applied only questionnaires which were classified as complete and suitable for further analysis. It was 791 questionnaires. Gathered data were edited what enabled its analysis and interpretation. Research constitute significant cognitive material and the knowledge that comes from it can serve as a basis to formulate marketing strategies by the entrepreneurs working in a food sector of young consumers in the border areas.

7 Return translation means translating a text from language of country A (language of original) into language of country B by the translator from country B. Then, version from language of country B is translated again into language of country A by the translator of country A (Karcz 2004, p.196). 


\section{Characteristic of researched collective}

Section of the young consumers is a subject of research due to the fact that they constitute future section of recipients. Nowadays, people creating this group are often sensitive, familiar with the world of consumerism and mature in their decisions (Bartosik-Prugat 2011, p. 97). This is also the age group that is characterized by low levels of neofobia, it is the fear of new things or experiences. (Babicz-Zielińska, Jeżewska-Zychowicz, Tańska 2013, s. 229).

791 persons participated in a research, most of them were women who constituted $60 \%$. Selection criterion for a research was an age between 18-29 years. Inhabitants of rural areas constituted one third, the other ones were living in city areas (usually of 50000-100000 inhabitants). The smallest group were German consumers, who constituted less than 10\%, this group will be enlarged in further stages of research.

\section{Attitudes of young consumers towards innovations on the food market in the light of survey research}

One of the issue mentioned in this research was to determine the types of decisions prevailing during purchase of food products. Research made by the author show that more than a half of the people being investigated are driven by habits, that is often with habitual decisions (table 1). The highest tendency to habitual decisions declared Czech (69\% of respondents) and Polish $(67 \%$ of respondents) consumers. Early research of the author also show that food habits significantly determine purchasing attitudes, especially among Polish consumers (on fifth place as a criterion of food purchase). In case of other nationalities, food habits were on further places (Barska 2013, p. 119). Significant role of the habits in a process of purchasing food products by the Polish consumers is also proved by the results of other research (Sojkin, Małecka, Olejniczak, Bakalarska 2009, p. 41). Every fifth declared that they make decisions concerning purchase of food products under influence of emotions, in this group prevailed Slovakian consumers. Equally numerous group of respondents declared that they make thoughtful decisions using numerous sources of information, every fourth German consumer declares that. 3 out of 100 couldn't characterize their purchase decisions concerning food (table 1). Emotional attitude to the process of making decisions in the sphere of food products declared every fifth woman $(21 \%)$, the similar result was among men $-21 \%$. Most women (58\%) admitted that they are driven by habit in their purchase decisions, this rate among men was - 
$52 \%$. Every fifth woman and every fourth man declared a consideration of their purchase decisions using numerous sources of information. To sum up, women are often driven by habits, whereas men have a tendency to the higher analysis of market offer. It can result from the fact that men less often buy food products and their decisions require higher consideration and more information.

Table 1. Behaviours of the respondents while purchasing food products

\begin{tabular}{l|c}
\hline \multicolumn{1}{c|}{ Behaviour description } & $\begin{array}{c}\text { Percentage } \\
\text { of } \\
\text { indications }\end{array}$ \\
\hline $\begin{array}{l}\text { Decisions about purchase of food products is made under influence of emotions } \\
\text { ("impulsive decisions") }\end{array}$ & 21 \\
\hline $\begin{array}{l}\text { Long considerations of decisions about the purchase of food products using } \\
\text { numerous sources of information ("thoughtful decisions") }\end{array}$ & 21 \\
\hline During purchase of food products is driven by habit "habitual decisions") & 55 \\
\hline No answer & 3 \\
\hline
\end{tabular}

Source: own survey on the basis of conducted research

In the researched group, the highest tendency to buy innovative products soon after they appeared on the market have German consumers. No "dawdlers" were identified among German consumers. In their group, the highest participation of early followers was noticed (59\%). Only $5 \%$ of the participation of innovators were identified in the group of Polish consumers. Almost every third Polish consumer declared that he/she quickly buys innovative food products, but after consideration what gives a basis for their classification to the group of the so-called early majority. Among Czech consumers, the group of "early majority" prevailed (32\%), that is the clients declaring that they buy innovative food products after they are tested by their acquaintances and family. Among Slovakian consumers, the biggest group was the so-called late majority - $28 \%$ (table 2). In the group of young consumers, participation of the innovators is considerably higher than in the Rogers model concerning the whole population, what may prove that adaptation of innovations on the food market depends on the age. Young consumers much quicker accept innovations on the food market, despite the fact that there is often purchase conservatism on this market. It is also confirmed by other investigators (Sojkin, Małecka, Olejniczak, Bakalarska 
2009, p. 121). Analysis of obtained empirical material let use notice that nationality differentiates people in respect to tendency to buy new food products. It seems that young German consumers more often buy novelties. However, this thesis requires verification, especially due to the fact that a group of German consumers was the smallest. The author's intention is a thorough investigation of this phenomenon in future research.

Table 2. Attitudes of respondents towards innovative food products

\begin{tabular}{|c|c|c|c|c|}
\hline \multirow[b]{2}{*}{ Declared attitude } & \multicolumn{4}{|c|}{$\begin{array}{l}\text { Country of origin of the respondent } \\
\text { ( } \% \text { of indications })\end{array}$} \\
\hline & 胥 & 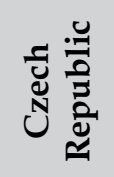 & $\begin{array}{l}\frac{\pi}{\sigma} \\
\frac{\pi}{\sigma} \\
\frac{\partial}{\omega}\end{array}$ & 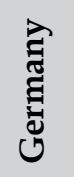 \\
\hline $\begin{array}{l}\text { I buy innovative food products soon after they were } \\
\text { on sale. I like having new products (the so-called } \\
\text { „innovators") }\end{array}$ & 5 & 7 & 7 & 14 \\
\hline $\begin{array}{l}\text { I quickly buy innovative food products but after } \\
\text { consideration (the so-called "early followers") }\end{array}$ & 31 & 17 & 23 & 59 \\
\hline $\begin{array}{l}\text { I buy innovative food products after they are tested } \\
\text { by my acquaintances and family (the so-called "early } \\
\text { majority") }\end{array}$ & 26 & 32 & 26 & 10 \\
\hline $\begin{array}{l}\text { I buy innovative food products when most of my } \\
\text { acquaintances bought them and recommended (the } \\
\text { so-called "late majority") }\end{array}$ & 20 & 27 & 28 & 17 \\
\hline $\begin{array}{l}\text { I reluctantly buy new food products. I have my } \\
\text { favourite and do not want to change them (the so- } \\
\text { called "dawdlers") }\end{array}$ & 16 & 17 & 13 & 0 \\
\hline Lack of indications & 2 & 0 & 3 & 0 \\
\hline Total & 100 & 100 & 100 & 100 \\
\hline
\end{tabular}

Source: own survey on the basis of conducted research

It is noteworthy that the rate of participation among men who are reluctant towards new food products was considerably higher than among women. 
Analysis of obtained material allows for a conclusion that women are more reluctant to buy new food products and also more often are influenced by recommendation of acquaintances (every fourth woman and every fifth man). Both among the group of men and women, every fourth person declared that he/ she buys innovative food products after they are tested by their acquaintances and family. That is why the group called early majority is the least diverse in terms of gender (table 3).

\section{Table 3. Attitudes of respondents towards innovative food products and gender}

\begin{tabular}{l|c|c}
\hline \multicolumn{1}{c|}{ Declared attitude } & $\begin{array}{c}\text { Division according to gender } \\
\text { (\% of indications) }\end{array}$ \\
\cline { 2 - 3 } & Female & Male \\
\hline $\begin{array}{l}\text { I buy innovative food products soon after they were on sale. I } \\
\text { like having new products }\end{array}$ & 6 & 5 \\
\hline I quickly buy innovative food products but after consideration & 30 & 28 \\
\hline $\begin{array}{l}\text { I buy innovative food products after they are tested by my } \\
\text { acquaintances and family }\end{array}$ & 26 & 26 \\
\hline $\begin{array}{l}\text { I buy innovative food products when most of my acquaintances } \\
\text { bought them and recommended }\end{array}$ & 26 & 21 \\
\hline $\begin{array}{l}\text { I reluctantly buy new food products. I have my favourite and } \\
\text { do not want to change them }\end{array}$ & 12 & 18 \\
\hline Lack of indications & 1 & 2 \\
\hline Total & 100 & 100 \\
\hline
\end{tabular}

Source: own survey on the basis of conducted research

Investigated people were asked to assess their income situation. Almost half of them described their income situation as very good and good (47\% of respondents), four out of ten described their situation as sufficient and one out of ten as insufficient. $4 \%$ did not agree to assess their income situation. Analysing the assessment of income situation in particular groups, we can notice that almost half of the people in "late majority" group of and the socalled "dawdlers" were the people who assess their income situation as very 
good (49,4\% and 46,4\%, respectively) (table 4). People assessing their income situation as a sufficient more often expressed interest to buy new product soon after they appeared on the market. Such a behaviour can be explained by the fact that, in a moment of introduction of new food products to the market, many producers use different forms of sale activation what can draw attention of less abundant consumers. K. Gutkowska (2011, p. 112) in her research had similar observations. And we can draw a conclusion that attitudes of young consumers towards innovations on the market of food products are not determined by good or very good income situation.

Table 4. Attitudes of respondents towards innovative food products and their subjective assessment of the income situation

\begin{tabular}{|c|c|c|c|c|}
\hline \multirow[b]{2}{*}{ Declared attitude } & \multicolumn{4}{|c|}{$\begin{array}{c}\text { Assessment of your income situation ( } \% \text { of } \\
\text { indications) }\end{array}$} \\
\hline & 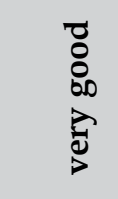 & 范 & 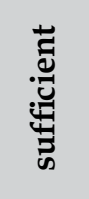 & 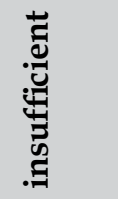 \\
\hline $\begin{array}{l}\text { I buy innovative food products soon after they } \\
\text { were on sale. I like having new products (the so- } \\
\text { called „innovators") }\end{array}$ & 15,4 & 46,1 & 35,9 & 2,6 \\
\hline $\begin{array}{l}\text { I quickly buy innovative food products but after } \\
\text { consideration (the so-called "early followers") }\end{array}$ & 6,7 & 38,3 & 43 & 12 \\
\hline $\begin{array}{l}\text { I buy innovative food products after they are tested } \\
\text { by my acquaintances and family (the so-called } \\
\text { „early majority") }\end{array}$ & 9,7 & 39 & 41,6 & 9,7 \\
\hline $\begin{array}{l}\text { I buy innovative food products when most of my } \\
\text { acquaintances bought them and recommended (the } \\
\text { so-called "late majority") }\end{array}$ & 49,4 & 29,1 & 17,7 & 3,8 \\
\hline $\begin{array}{l}\text { I reluctantly buy new food products. I have my } \\
\text { favourite and do not want to change them (the so- } \\
\text { called "dawdlers") }\end{array}$ & 46,4 & 29,9 & 17,5 & 6,2 \\
\hline
\end{tabular}

Source: own survey on the basis of conducted research 


\section{Conclusion}

Young consumers are open to novelties, although the rapidity of acceptance of innovations is diverse depending on the country of origin. They impose high requirements to the producers of food and they are aware consumers who know very well what they expect from a new product. Purchase decisions of the young consumers is not only determined by the will to try them, but also by attractive price. Earlier research of the author show that in all of the countries, as a four main selection criteria of food products were indicated: freshness of a product, price, quality and taste values (Barska 2013, p. 119). Conducted research prove that young people accept new products, that is why this group should be taken into consideration by the marketing specialists in their marketing activities. It is noteworthy that innovators, and especially early followers create market for new brands and new products on the market - in the first place by manifestation of their use in front of the followers, and then by popularizing positive attitude towards them. Successful use of the young consumers in a force market role requires thorough recognition of their attitudes and behaviours, what will allow to reach to them through proper marketing activities. As a result, it can decide about the success or failure of introduction of new product to the market (Gutkowska 2011, p. 109).

\section{Summary}

Attitudes of young consumers towards innovations on the food market

In this article, the author presents the results of her own surveys concerning attitudes of young consumers - living in the border areas of Poland, Czech Republic, Slovakia and Germany - towards innovation on the market of food products. Innovative food is positively accepted by the young consumers, although it should be noted that large group of consumers are driven by the habits, especially Polish and Czech consumers. The process of diffusion of innovations on the food market among young consumers depends on the country they live in, gender (women considerably faster accept innovations) but is not determined by high incomes.

Key words: innovations, young consumer, consumer behaviour, diffusion of innovations. 


\section{Streszczenie}

\section{Postawy młodych konsumentów wobec innowacji na rynku żywności}

W niniejszym opracowaniu autorka prezentuje wyniki własnych badań ankietowych dotyczących postaw młodych konsumentów - zamieszkujących tereny przygraniczne Polski, Czech, Słowacji i Niemiec - wobec innowacji na rynku produktów żywnościowych. Jak zauważono, innowacyjna żywność jest pozytywnie przyjmowana przez młodych konsumentów, choć należy zauważyć, że znaczna grupa konsumentów kieruje się przyzwyczajeniem, dotyczy to szczególnie polskich i czeskich konsumentów. Proces dyfuzji innowacji na rynku żywności wśród młodych konsumentów jest uzależniony od kraju pochodzenia nabywców, płci (kobiety znacznie szybciej akceptują innowacje) natomiast nie jest determinowany wysokimi dochodami

\section{Słowa}

klucze:

innowacje, młody konsument, zachowania konsumentów, dyfuzja innowacji.

\section{References:}

1. Babicz-Zielińska E., Jeżewska-Zychowicz M., Tańska M. (2013), Neofobia a zachowania konsumentów na rynku nowej żywności, w: A. Olejniczuk-Merta (red.), Konsumpcja w innowacyjnej gospodarce, "Handel Wewnętrzny”, styczeń.

2. Barska A. (2013), Kryteria wyboru produktów żywnościowych przez młodych konsumentów z Czech, Polski i Stowacji, "Zagadnienia Ekonomiki Rolnej”, $\mathrm{Nr} 4$.

3. Bartosik-Purgat M. (2011), Kulturowe uwarunkowania zachowań konsumentów na przykładzie młodych Europejczyków, Wyd. UE, Poznań.

4. Bywalec Cz. (2010), Konsumpcja a rozwój gospodarczy i społeczny, C.H. Beck, Warszawa.

5. Citrin A.V., Sprott D.E., Silverman S.N., Stem D.E. (2000), Adoption of Internet shopping: the role of consumer innovativeness, "Industrial Management \& Data Systems", Vol. 100 (7).

6. Frąckiewicz E. (2004), Innowacje marketingowe w procesie tworzenia wartości dla klienta, Prace Naukowe AE we Wrocławiu, Nr 1030, Wrocław.

7. Goldsmith R.E., Flynn L.R. (1992), Identifying innovators in consumer product markets, "European Journal of Marketing", Vol. 26, No. 12.

8. Gutkowska K., Ozimek I. (2005), Wybrane aspekty zachowań konsumentów na rynku żywności - kryteria różnicowania, SGGW, Warszawa. 
9. Gutkowska K. (2011), Innowacyjność konsumentów wobec produktów żywnościowych jako warunek rozwoju rynku ̇̇ywności, „Konsumpcja i Rozwój", Nr 1.

10. Jeżewska-Zychowicz M., (2008), Ocena innowacyjności konsumentów na rynku żywności z uwzględnieniem opakowań produktów żywnościowych, w: M. Adamowicz (red.), Innowacje i innowacyjność w agrobiznesie Wyd. SGGW, Warszawa.

11. Karcz K. (2004), Międzynarodowe badania marketingowe. Uwarunkowania kulturowe, PWE, Warszawa.

12. Kotler Ph. (2004), Marketing. Analiza, planowanie, wdrażanie i kontrola, Gebethner i S-ka, Warszawa.

13. Kowalczuk I. (2011), Innowacyjna ̇̇ywność w opinii konsumentów i producentów, SGGW, Warszawa.

14. Makarski S. (2013), Konsumpcje konsumentów wyznacznikiem poziomu ich innowacyjności w: A. Olejniczuk-Merta (ed.), Konsumpcja w innowacyjnej gospodarce, "Handel Wewnętrzny”, styczeń.

15. Mazurek-Łopacińska K. (2003), Zachowania nabywców i ich konsekwencje marketingowe, PWE, Warszawa.

16. Mruk H. (2007), Makrotrendy a zachowania konsumentów, w: Z. Kędzior (ed.), Konsument - Gospodarstwo domowe - Rynek, Centrum Badań i Ekspertyz, AE Katowice, Katowice.

17. Pilarczyk B. (2011), Innowacje w komunikacji marketingowej, Zeszyty Naukowe Polskiego Towarzystwa Ekonomicznego, Nr 9, Kraków.

18. Rogers E.M. (1983), Diffusion of Innovations, The Free Press, New York London.

19. Słaby T. (2006), Konsumpcja. Eseje statystyczne, Difin, Warszawa 2006.

20. Sojkin B., Małecka M., Olejniczak T., Bakalarska M. (2009), Konsument wobec innowacji produktowych na rynku żywności, Wyd. UE, Poznań.

21. Taranko T. (2013), Zmiany zachowań konsumentów i ich wptyw na kształtowanie produktów, "Marketing i Rynek”, Nr 3.

22. Toffler A. (1997), Trzecia fala, Państwowy Instytut Wydawniczy, Warszawa.

23. Wziątek-Kubiak A., Balcerowicz E. (2009), Determinanty rozwoju innowacyjności firmy w kontekście poziomu wykształcenia pracowników, PARP, Warszawa.

24. Zalewski R.I. (2004), Zarządzanie jakością w produkcji żywności, Wyd. AE, Poznań. 